\section{Recurrences in nonseminomatous germ cell testicular tumors with no viable cancer at postchemotherapy retroperitoneal lymphadenectomy}

Argirovic M. Djordje ${ }^{1}$, Argirovic Dj. Aleksandar ${ }^{2}$

${ }^{1}$ Clinic of Urology, CCS, Outpatient Clinic „Argirović“, Urology, Belgrade, Serbia

${ }^{2}$ Clinical Hospital Center Zemun-Belgrade, Department of Urology, Zemun, Serbia

\section{Abstract}

This sudy is performed to determine disease related outcome in metastatic nonseminomatous germ cell testicular tumors (NSGCTTs) in patients with absence of viable cancer (VC) in the postchemotherapy retroperitoneal lymphadenectomy (PC-RPLA) specimen and determine wheter clinical variables can help predict disease progression. Among a survey of 163 patients submitted to PCRPLA from 1980-2005, 126 patients (77\%) had no VC (44 fibrosis, 82 teratoma). At mean followup (MFU) of $158+/-77.7$ months, 20 patients $(16 \%)$ developed recurrences within median free interval of 19.3 montha, with complete response (CR) following applied therapy in 9 patients (45\%). Eleven patients $(8 \%)$ diead (8 of disease, 3 of other causes). Predictors for poorer recurrence free survival (RFS) were advanced clinical stage $(\mathrm{CS})(\mathrm{P}<0.016)$, intermediate/ poor IGCCCG group $(\mathrm{p}<0.004)$, and PC-RPLA nodal size $(p<0.0007)$, while for disease-speciphic survival (DSS) included recurrences $(\mathrm{p}<0.0001), P C$ $\mathrm{RP}$ residual mass $(\mathrm{RM})$ diameter $((\mathrm{p}<0.006)$, worse IGCCCG risk $(\mathrm{p}<0.0003)$ and increased HCG at PCRPLA $(\mathrm{p}<0.0001)$. A subset analysis of potential predictors of poorer RFS in patients with fibrosis identified only worse IGCCCG risk $(\mathrm{p}=0.05$ ), whereas in teratoma were worse IGCCCG risk classification $(\mathrm{p}=0.01)$, PC RP RM size $(\mathrm{p}<0.0005)$ and unfavorable histology (teratoma with malignant transformation $[\mathrm{TMT}]$ vs. mature teratoma $[\mathrm{MT}] /$ immature teratoma $[\mathrm{IMT}])(\mathrm{p}<0.0001)$. Adverse impact on DSS in fibrosis had elevated HCG on PC-RPLA $(p<0.013)$ and in teratoma the presence of unfavorable IGCCCG risk $(\mathrm{p}<0.0001)$, worse RP histology $(\mathrm{p}<0.05)$ and postoperative recurrence $(\mathrm{p}<0.0001)$. The 5-year DSS and RFS rates for all patients with no VC at PCRPLA were $87 \%$ and $85 \%$, while at 10 -year were $79 \%$ and $75 \%$, respectively (Log rank $=13.155 ; \mathrm{p}<0.003$ ).

\section{Recidivi kod nesiminomskih tumora germinativnih ćelija testisa bez vitalnog karcinoma na posthemioterapijskoj retroperitonealnoj limfadenektomiji}

Argirović M. Đorđe ${ }^{1}$, Argirović Đ. Aleksandar ${ }^{2}$

${ }^{1}$ Urološka Klinika, KCS, Poliklinika „Argirovićc“, Urologija, Beograd, Srbija

${ }^{2}$ Služba urologije, Kliničko Bolnički Centar Zemun-Beograd, Srbija

\section{Apstrakt}

Ova studija je provedena da analizira ishod kod neseminomskih tumora germinativnih ćelija testisa (NSTGĆT) kod pacijenata sa odsustvom vitalnog karcinoma (VK) u uzorku posthemioterapijske retroperitonealne limfadenektomije (PH-RPLA) i da odredi koliko kliničke varijable mogu pomoći u predvidjanju progresije bolesti. U seriji od 163 pacjenta podvrgnutih PH-RPLA od 1980-2005, 126 pacijenata (77\%) nije imalo VK (44 fibrozu, 82 teratom). Pri srednjem praćenju od 158+/-77.7 meseci, 20 pacijenata (16\%) je imalo recidiv unutar srednjeg slobodnog intervala od 19.3 meseci, sa kompletnim odgovorom posle primenjene terapije kod 9 pacijenata (45\%). Jedanaest pacijenata ( $8 \%$ ) je umrlo (8 od osnovne bolesti, 3 iz drugih razloga). Pokazatelji za lošije preživljavanje bez recidiva bolesti (PRB) su bili uznapredovali klinički stadijum $(K S)(p<0.016)$, srednja/loša IGCCCG rizična grupa $(\mathrm{p}<0.004)$ i PH-RPLA veličina rezidualne mase $(R M)(p<0.0007)$, dok je preživljavanje specifično za bolest (PSB) podrazumevalo recidive $(\mathrm{p}<0.0001)$, dijametar PH RP RM $(p<0.006)$, lošu IGCCCG rizičnu grupu $(p<0.003)$ i povišene vrednosti HCG pre PH-RPLA $(\mathrm{p}<0.0001)$. Analiza potencijalnih prediktora lošeg PRB kod pacijenata sa fibrozom je identifikovala samo lošu IGCCCG rizičnu grupu $(\mathrm{p}=0.05)$, dok su kod teratoma bili lošija IGCCCG rizična grupa ( $\mathrm{p}=0.01)$, veličina PH RP RM ( $<<0.0005)$, i nepovoljna RP histologija (teratom sa malignom transformacijom prema zrelom teratomu/nezrelom teratomu) $(p<0.0001)$. Nepovoljan uticaj na PSB kod fibroze je imao povišen HCG pri PH-RPLA $(\mathrm{p}<0.019)$, a kod teratoma prisustvo nepovoljne IGCCCG rizične grupe $(p<0.001)$, loše RP histologije $(p<0.05)$ i postoperativnih recidiva $(\mathrm{p}<0.0001)$. Petogodišnje PSB i RSB za sve pacijente bez VK na PH-RPLA je bilo $87 \%$ i $85 \%$, dok je desetogodišnje iznosilo $79 \%$ i $75 \%$, respektivno (Log rank=13.155; $\mathrm{p}<0.003)$. Kod pacijenata

MATERIA MEDICA • Vol. 29 • No. 4 • decembar 2013. 
Patients with no VC at PC-RPLA remain at risk of recurrence. Several clinical variables, including CS, intermediate/poor IGCCCG group, preoperative HCG level, diameter of RP RM and postoperative recurrence help better to define which patients are at risk of disease recurrence and survival; as such these patients should be followed regularly in the postoperative period.

Key words: germ cell testicular tumors, nonseminoma, chemotherapy, retroperitoneal lymphadenectomy, fibrosis, teratoma. bez nalaza VK na PH-RPLA postoji rizik za pojavu recidiva. Više kliničkih varijabli, uključujući KS, srednju/lošu IGCCCG rizičnu grupu, preoperativni nivo HCG, dijametar RP RM i postoperativni recidiv, pomažu nam da bolje definišemo koji pacijenti imaju veći rizik za recidiv bolesti i preživljavanje. U tim slučajevima, ovi pacijenti moraju biti redovno praćeni u postoperativnom periodu.

Ključne reči: tumori germinativnih ćelija testisa, neseminomski, hemioterapija, retroperitonealna limfadenektomija, fibroza, teratom.

\section{Introduction}

Patients with advanced NSGCTTs are often treated with cisplatin (CDDP)-based chemotherapy followed by surgical resection, which commonly results in cure rate exceeding $90 \%{ }^{1-5}$. It was recently reported that $16 \%$ of patients with no VC in resected specimen at surgery had disease recurrence ${ }^{6}$. The aim of the present study was to review the disease related outcomes for patients with metastatic NSGCTTs exibiting no VC elements at the time of PC-RPLA and determine wheter clinical parameters can help better define which patients are at risk of disease progression.

\section{Material and methods}

\section{Patient population}

Among a survey of 163 patients submitted to PC-RPLA due to metastatic NSGCTTS between 1980 and 2005, 126 pateints (77\%) had no VC in the resected specimen (44 [35\%] and 82 [55\%] teratoma). Patients undergoing extraretroperitoneal surgery were not included in this study because our previous analysis demonstrated that these patients may be at higher risk of relapse and progression independent of tumor histology at surgery ${ }^{7}$. Clinical stage was determined according to the 2009 TNM staging system, and patients were classified according to International Germ Cell Consensus Classification Group (IGCCCG). At the time of diagnosis, all patients had a complete medical evaluation including serum tumor markers (STMs) and radiologic imaging consisting of chest and abdominal/pelvic computed tomography (CT). Some of the patients evaluated in the early 1980s were assessed by lymphangiography alone in terms of preoperative staging.

\section{Data collection}

Clinical, pathologic, and laboratory data were reviewed and entered into a surgical data base. All patients received systemic CDDP-based chemotherapy before PC- RPLA, with a median number of cycles bein five. Of our study population, 109 patients $(86,5 \%)$ were treated with 1 -st line chemotherapy, and 19 patients $(13.5 \%)$ received 2nd-line chemotherapy. Not all patients had normalization of STMs elevation before surgery, but procedeed to PC-RPLA if it was deemed that they had received the maximal amount of systemic chemotherapy and/or preoperative STMs elevation was suspected to be due to other causes (eg, hypogonadism, liver dysfunction, illicit drug use). PC-RPLA was performed in all patients with radiologic evidence of a RM after CDDP-based chemotherapy for metastatic NSGCTTs. Fully bilateral PC-RPLA was performed in 60 patients $(47.6 \%)$ and with modified template in 102 patients $(52.4 \%)$. However, 8 patients (6.3\%) underwent aditional procedures in absence of other suspecte sites of disease but rather owing to the local extent of their RP RM (nephrectomy in 5, small bowel resection in 1, renal veins grafting 2).

Postoperatively, patients were followed by history, physical examination, STMs and abdominal/pelvic 
ultrasound examination every 3 to 6 months, with chest $\mathrm{x}$-ray and abdominal/pelvic CT imaging every 6 to 12 months (or earlier if required). None of the patients in the present study received adjuvant chemotherapy due to the absence of VC elements in the PC-RPLA specimen.

Statistical analysis

The median age and range of values are reported for age at diagnosis, STMs at orchiectomy and before PC-RPLA, number of chemotherapy cycles before PC-RPLA and largest diameter of RP mass (preoperatively and postoperatively).

Using Cox proportional hazards regression modeling, we tested the statistical significance of several potential prognostic factors in predicting DSS and RFS. A univariate model was performed initially, and we estimated the hazards ratio for each potential prognostic factor, including the $95 \%$ confidence interval. All potential prognostic factors with a $p$ value of $<0.25$ on univariate analysis were then included in a saturated model on the basis of the likelihood ratio test in the multivriate regression analysis. The methods of Kaplan and Meier were used to estimate the median DSS and RFS and the difference were assessed with the log-rank statistics. Statistical significance in this study was set at $\mathrm{p}<0.05$.

\section{Results}

Table 1. reporte age of patients at diagnosis, values of STMs before chemotherapy and before PC-RPLA, number of chemotherapeutical cycles before PC-RPLA and longest diameter of RP mass before chemotherapy and PC-RPLA. The MFU of the whole cohort of patients was 157.8+/-77.7 months (range, 2-280). (Table 1.)

\begin{tabular}{|l|l|l|l|}
\hline VARIABLES & MEAN & MEDIAN & RANGE \\
\hline Age at diagnosis (yrs) & 29.2 & 28.6 & $15-58$ \\
\hline STM before C & & & \\
AFP $(\mathrm{ng} / \mathrm{ml})$ & 3219.7 & 71.9 & $0-49.46$ \\
HCG (mIU/ml) & 17267.7 & 33.1 & $0-600.065$ \\
LDH (IU/L) & 946.8 & 486 & $135-8856$ \\
STM before PC-RPLA & & & \\
AFP (ng/ml) & 10.7 & 3.2 & $1-7.5$ \\
HCG (mIU/ml) & 3.9 & 1 & $1-343$ \\
LDH (IU/L) & 481.8 & 435 & $113-600$ \\
No. of C cycles before PC-RPLA & 6.7 & 5 & $2-20$ \\
Largest diameter of RP mass on pre-op C $(\mathrm{cm})$ & 5.7 & 4.7 & $1-25$ \\
Largest diameter of RP mass on PC-RPLA $(\mathrm{cm})$ & 4.3 & 3.5 & $0.6-20$ \\
\hline
\end{tabular}

Table 1. Clinical characteristics of study population

\section{Patient characteristics}

The clinical characteristics of our study subjects are shown in Table 2. 


\begin{tabular}{|l|l|}
\hline VARIABLES & NO. OF PATIENTS (\%) \\
\hline Induction C & $109(86.5)$ \\
$1^{\text {st line }}$ & $19(13.5)$ \\
$2^{\text {nd }}$ line & \\
Clinical stage & $42(33)$ \\
IIA/IIB & $84(77)$ \\
IIC/III & $85(67)$ \\
IGCCCG risk classification & $41(33)$ \\
Good & $71(56.3)$ \\
Intermediate/poor & $55(43.7)$ \\
Histology & \\
With teratoma compound & $49(38.9)$ \\
Without teratoma compound & $77(61.1)$ \\
PC RM nodal size, cm & \\
\hline$<5$ & $>5$
\end{tabular}

Table 2. Clinical characteristics of study population

Most of the patients presented with advanced CS of disease (77\%), RP RM size measuring $>5 \mathrm{~cm}$ in diameter was found in 77 patients (61\%), teratoma in the orchiectomy specimen was present in 71 patients (56\%), while IGCCCG risk classification occurred in 41 patients (33\%). The median STMs level of patients before PC-RPLA were AFP $3.2 \mathrm{ng} / \mathrm{mL}, \mathrm{HCG} 1 \mathrm{mIU} / \mathrm{mL}$ and LDH $435 \mathrm{IU} / \mathrm{L}$. All of the patients had no VC in the surgical specimen; rather fibrosis was identified in 44 patients $(35 \%)$ and teratoma in 82 patients $(65 \%)$.

Fate and survival of patients with no VC at PC-RPLA

Of the 126 patients with no VC at PC-RPLA, 20 (16\%) developed recurrence within median free interval of 19.3 months (range, 13-288). The sites of relapses were RP LN ( $\mathrm{n}=15)$, chest $(\mathrm{n}=2)$, liver $(\mathrm{n}=1)$, brain $(\mathrm{n}=1)$ and only elevated STMs $(\mathrm{n}=1)$. Complete remission following applied salvage therapy in recurrence occurred in 9 patients $(45 \%)$.

\section{Predictors of relapse free survival}

Predictors for poor RFS were advanced CS $(\mathrm{p}<0.016)$, intermediate/poor IGCCCG risk classification $(\mathrm{p}<0.0004)$, and PC RP nodal size $(\mathrm{p}<0.0007)$. A subset analysis of potential predictors of poorer RFS in patients with fibrosis only within PC-RPLA specimen were IGCCCG risk classificaton $(\mathrm{p}<0.05)$, whereas in teratoma were worse IGCCCG risk categorisation $(p<0.01)$, PC RP RM size $(p<0.0005)$ and unfavorable histology at PC-RPLA (TMT vs. MT/IMT)(Table 3.). 


\begin{tabular}{|c|c|c|c|c|}
\hline CHARACTERISTICS & $\begin{array}{c}\text { RFS } \\
\text { NO. PTS (\%) }\end{array}$ & OR & $95 \% \mathrm{Cl}$ & p \\
\hline \multicolumn{5}{|l|}{ Initial clinical stage } \\
\hline$\|A\| B,(n=42)$ & $40(95)$ & 5.45 & $1.202-24.759$ & $<0.016$ \\
\hline IIC,III (n=84) & $66(79)$ & & & \\
\hline \multicolumn{5}{|l|}{ PC-RM, diameter, $\mathrm{cm}$} \\
\hline$<5(n=49)$ & $47(96)$ & 14.64 & $1.886-113.68$ & $<0.0007$ \\
\hline$>5(n=77)$ & $59(75)$ & & & \\
\hline \multicolumn{5}{|l|}{ IGCCCG risk classification } \\
\hline Good (n=85) & $77(91)$ & 3.98 & $1.477-10.732$ & $<0.004$ \\
\hline Intermediate/poor $(n=41)$ & $29(71)$ & & & \\
\hline
\end{tabular}

Table 3. Factors associated with RFS at PC-RPLA without VC

\section{Predictors of disease- speciphic survival}

Predictors of poorer DSS included postoperative recurrence ( $p<0.0001)$, PC RP RM size ( $<<0.006)$, worse IGCCCG classification $(p<0.0003)$ and increased HCG at PC-RPLA $(p<0.001)$. Adverse impact on DSS in fibrosis had elevated HCG at PC- RPLA $(\mathrm{p}<0.013)$, and in teratoma the presence of unfavorable IGCCCG risk classification $(p<0.0001)$, worse RP pathology $(p<0.05)$ and postoperative recurrences $(p<0.0001)$. An HCG level of $1.2 \mathrm{mIU} / \mathrm{mL}$ before PC-RPLA trended toward statistical significance $(\mathrm{p}=0.07)$, while pathologic diameter of RP RM $>2.5 \mathrm{~cm}$ was statistically significant $(\mathrm{p}=0.05)$ in predicting poorer DSS for patients with no $\mathrm{VC}$ at the time of PC-RPLA. Among $13(15 \%)$ relapsing teratoma on redo-RPLA, $6(46 \%)$ had worse histology, with survival in only 1 patient $(17 \%)$ vs. 6 of 7 (87\%) with MT/IMT ( $p<0.0001)$ (Table 4.).

\begin{tabular}{|c|c|c|c|c|}
\hline CHARACTERISTICS & $\begin{array}{c}\text { DSS } \\
\text { NO. PTS (\%) }\end{array}$ & OR & $95 \% \mathrm{Cl}$ & p \\
\hline \multicolumn{5}{|l|}{ Recurrences } \\
\hline No $(n=106)$ & $106(100)$ & 257.84 & $14.072-4724.45$ & $<0.00001$ \\
\hline Yes $(n=20)$ & $9(41)$ & & & \\
\hline \multicolumn{5}{|l|}{ PC-RM size, diameter, $\mathrm{cm}$} \\
\hline$<5(n=49)$ & $49(100)$ & 17.12 & $0.985-297.523$ & $<0.006$ \\
\hline$>5(n=77)$ & $59(75)$ & & & \\
\hline \multicolumn{5}{|l|}{ IGCCCG risk classification } \\
\hline Good $(n=85)$ & $83(98)$ & 11.67 & $2.39-56.98$ & $<0.0003$ \\
\hline Intermediate/poor $(n=41)$ & $32(78)$ & & & \\
\hline \multicolumn{5}{|l|}{ Increased HCG at PC-RPLA } \\
\hline No $(n=123)$ & $123(100)$ & 411.66 & $13.24-1279.75$ & $<0.001$ \\
\hline Yes $(n=3)$ & $1(33)$ & & & \\
\hline
\end{tabular}

Table 4. Predicors associated with DSS at PC-RPLA without VC 
The Kaplan-Meier estimate the 5- and 10-year DSS were 93\% and 89\%, respectivealy. The 3-year RFS was 33\%.At MFU of $168.8+/-12.8$ and $44.0+/-21.7$ months, DSS and RFS are achieved in $93 \%$ and $91 \%$, respectively (Figure 1.)

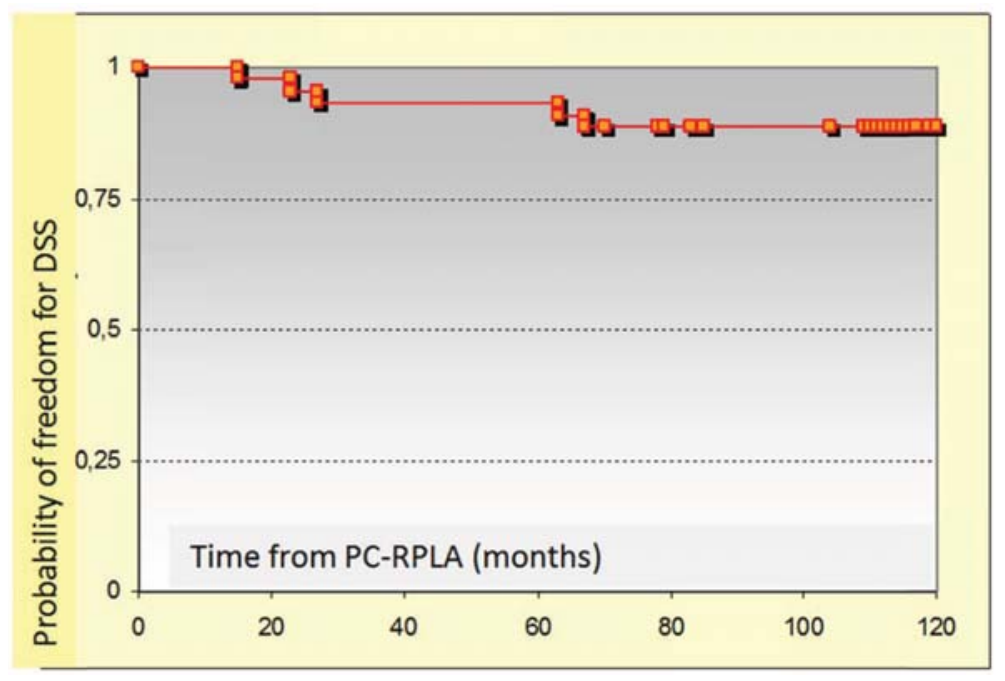

\begin{tabular}{|l|l|l|l|l|}
\hline & \multicolumn{4}{|c|}{ TIME (YRS) } \\
\hline & 5 yrs & $95 \% \mathrm{Cl}$ & 10 yrs & $95 \% \mathrm{Cl}$ \\
\hline DSS & $93.2 \%$ & $(89.9-96.5)$ & $88.6 \%$ & $(84.2-92.8)$ \\
\hline
\end{tabular}

Figure 1. DSS in patients with finding of fibrosis at PC- RPLA

The Kaplan-Meier estimate the 5-year DSS and RFS rates were $97 \%$ and $87 \%$, while at 10 -year rates were $88 \%$ and $81 \%$, respectively. At MFU of $155.50+7-62.80$ and $97.33+7-13.95$ months, DSS and RFS are achieved in $90 \%$ and $80 \%$, respectively (Figure 2 .)

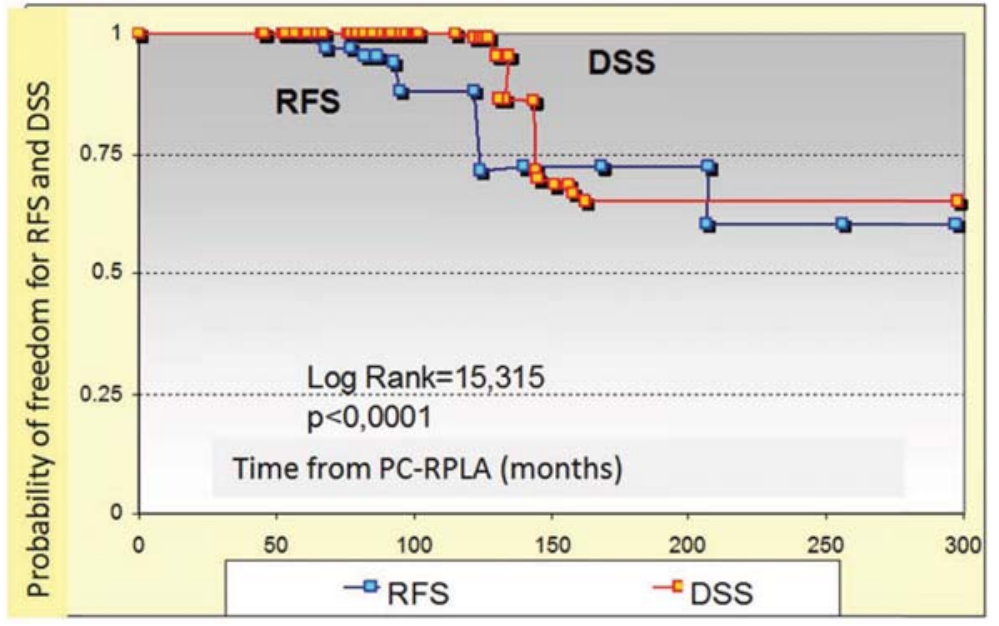

\begin{tabular}{|l|l|l|l|l|}
\hline & \multicolumn{4}{|c|}{ TIME (YRS) } \\
\hline & 5 yrs & $95 \% \mathrm{Cl}$ & 10 yrs & $95 \% \mathrm{Cl}$ \\
\hline DSS & $97.56 \%$ & $(95.86-99.26)$ & $88.54 \%$ & $(57.67-66.23)$ \\
\hline RFS & $87.5 \%$ & $(79.2-95.7)$ & $81.2 \%$ & $(71.4-89.9)$ \\
\hline
\end{tabular}

Figure 2. DSS and RFS in patients with finding of teratoma at PC-RPLA 
The Kaplan-Meier estimate the 5-year DSS and RFS rates for all patients without VC at PC-RPLA were $87 \%$ and $85 \%$, respectively, and at 10 -year rates were $79 \%$ and $75 \%$, respectively (Figure 3 .)

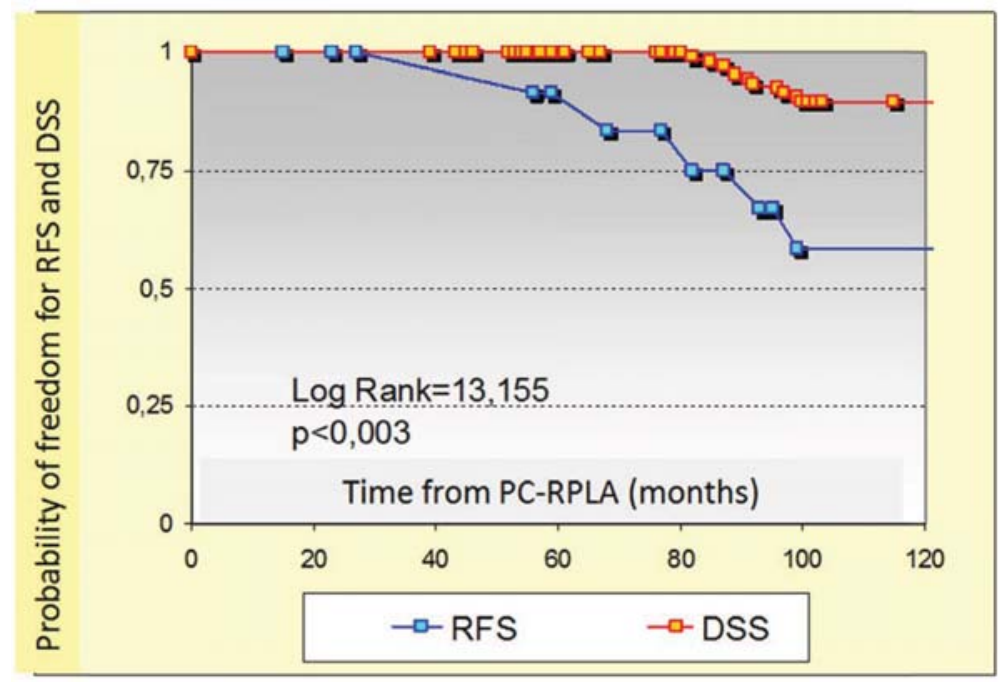

\begin{tabular}{|l|l|l|l|l|}
\hline & \multicolumn{4}{|c|}{ Time (yrs) } \\
\hline & 5 yrs & $95 \% \mathrm{Cl}$ & 10 yrs & $95 \% \mathrm{Cl}$ \\
\hline DSS & $87.30 \%$ & $(85.12-91.37)$ & $78.9 \%$ & $(74.67-83.23)$ \\
\hline RFS & $84.91 \%$ & $(81.43-87.92)$ & $75.38 \%$ & $(71.31-80.58)$ \\
\hline
\end{tabular}

Figure 3. DSS and RFS for all patients with no VC at PC-RPLA.

Overall, 115 patients (92\% are alive and free of disease at MFU of 157.8+/-77.7 (range,43-280), while 11 patients ( $8 \%$ ) died ( 8 of primary disease and 3 of other causes).

\section{Discussion}

Patients with no VC at the time of PC-RPLA performed for metastatic NSGCTT remain at an $18 \%$ risk of disease recurrence, clearly demonstrating that the absence of VC cells in the surgical specimen does not rule out risk of disease progression. Previous studies from Memorial Sloan Kettering Cancer Center and Indiana University would corroborate our findings, in that a small proportion of patients (5\% to $15 \%)$ with no VC in the PC- RPLA specimen can develop future disease recurrences ${ }^{8,9}$. Although it was not the primary end point of these prior studies to evaluate the rate and predictors of recurrence in this patients population, it clearly validates the importance of following these patients with STMs and radiologic imaging after PCRPLA. Furthermore, patients need to be counseled that although the absence of VC in the surgical specimen is a favorable feature, it does not guarantee the absence of future recurrence. The difference in our reported relapse rate and those of the two previous studies can best be explained by the higher proportion of patients with advanced CS in our study population.

These finding validate previously published postoperative surveillance protocol based on CS, which was developed on the basis of the pattern of recurrence at the time of PC-RPLA, and demonstrated the importance of CS in predicting risk of recurrence. Results providing from our study confirmed that the most frequent sites of recurrence were RP LN (15) and chest (2), with the majority of the recurrences occuring in patients with IIC and III (79\%). Furthermore, the present study demonstrates that patients classified as intermediate/ poor IGCCCG risk classification have an associated poorer RFS. However, the present study has a unique value, while separately indentified predictive factors associated with DSS and RFS according to the presence of fibrosis or teratoma at PC-RPLA. 
On multivariate analysis of potential predictors of DSS, an increasing HCG level before PC-RPLA were predictive of poorer DSS. A serum HCG level before PC-RPLA greater than $1.2 \mathrm{mIU} / \mathrm{mL}$ trended toward statistical significance in predicting poorer DSS in this patient population. Several other clinical variables were found to help predict DSS in patients with no VC, including diameter of RP mass measuring $>5 \mathrm{~cm}$ at PC-RPLA, recurrence of disease and intermediate/poor IGCCCG risk classification. The prognostic value of size of the RP mass or final pathology has not previously been reported and likely reflects the extent of disease in those who progress. A diameter of the RP mass greater than $2.5 \mathrm{~cm}$ is associated with poorer DSS in patients with no VC at PC-RPLA. Patients with no VC in whom a postoperative recurrence occurs have 43-fold higher risk of dying of disease than those without recurrence, which strongly supports an agressive treatment approach to patients with no $\mathrm{VC}$ at time of surgery who develop postoperative recurrence.

Several limitations to our study must be mentioned. This study is retrospective and therefore suffers from a selection bias common to all retrospective studies. Second, our attempts at selecting specifing cut points for preoperative serum HCG level and size of RP mass that discriminate disease-related outcomes among our patient population results in an over-fitting of our Cox models to the current dataset. Third, reporting of PC-RPLA pathology is based on our review of institutional pathology reports, therefore not all pathology specimens were read by the same pathologist. Last, our chemotherapeutic regimens have undergone considerable change over the last 20 years; as such this may have partly affected disease-related out-comes.

\section{Conclusion}

Patients with no VC after PC-RPLA should be followed carefully in the postoperative period because $16 \%$ of these patients are at risk of subsequent recurrence. Several clinical variables, including advanced CS, increazed size of the RP mass, and elevated HCG level before PC-RPLA, help better identified patients at risk of disease-specific recurrence and survival; as such, these patients should be followed regularly in the postoperative period.

\section{Acknowledgment}

Authors cordially thank to Natalija Šeparović, Hypo Alpe Adria, Hypo facilities servicies, Belgrade, Serbia for help in statistical analysis, and to Iva Popović from City_Image, Belgrade, Serbia for the technical assistance in the preparation and edition of this manuscript.

\section{Literature}

1. Stephenson AJ, Bosl GJ, Motzer AJ, Kattan MW, Stasi J, Bajorin DJ, Sheinfeld J. Retroperitoneal lymph node dissection for nonseminomatous germ cell tsticular cancer: ipact of patients selection factors on outcome. J Clin Oncol 2005;23:2781-8.

2. Donohue JP, Thornhill JA, Foster RS, Rowland RG, Bihrle R. Retroperitonel lymphadenectomy for clinical stage A testis cance (1965 to 1989): modification of technique and impact on ejaculation. J Urol 1993;149:237-43.

3. Donohue JP, Thornhill JA, Foster RS, Bihrle R, Rowland RG, Einhorn LH. The role of retroperitoneal lymphadenectomy in clinical stage B testis cancer: the Indiana University experience (1965 to 1989). J Urol 1995;153:85-9.

4. Logothetis CJ, Swanson DA, Dexeus F, Chong C, Ogden S, Ayala AG, et al. J Clin Oncol 1987;5:906-11.

5. Horwich A, Norman A, Fisher C, Hendry WF, Nicholls J, Dearnaley DP. J Urol 1994; 151:72-7.

6. Spiess PE, Brown GA, Liu P, Tu SM, Tannir NM, Evans JG, et al. J Urol 2007;177:131-8.

7. Argirovic D, Argirovic A. The impact of residual extra-retroperitoneal masses in patients with advanced nonseminomatous testicular tumors. Eur Urol Meet 2009;8:625. 
8. Toner GC; Panicek DM, Heelan RT, Galler NL, Lin S-Y, Bajorin Dj, et al. adjunctive surgery after chemotherapy for nonseminomatous germ cell tumors: recomendations for patient selection. J Clin Oncol 1990;8:1683-94.

9. Debono DJ, Heilman DK, Einhorn LH, Donohue JP. Decision analysis for avoiding postchemotherapy srgery in patients with dissemnated nonseminomatous germ cell tumors. J Clin oncol, 15:1455-64.

Corresponding author: Đorđe Argirović Outpatient Clinic „Argirović“, Urology Cvijićeva 84A

11.120 Belgrade, Serbia Tel.: + 381112788498,2787900 Fax./Tel.: + 381113290324 Mob.: +38163236659

E-mail: djordje.argirovic@gmail.com 